\title{
The Shortcomings of Rationalist Claims: Carbon Taxation and Political-Economy Approaches to Climate Change
}

\section{Ardhi Arsala Rahmani}

Universitas Indonesia

Email: ardhiarsala@gmail.com

\begin{abstract}
As the devastating impacts of climate change continue to loom across the world, it comes to a surprise then why responses by nation-states have been too slow and lacking for a supposed destructive, debilitating and critical-to-survival threat. This then negates the rationalist perspectives of the states which assume that playing games of survival are what nationstates do on a day-to-day basis. To that end, this paper proposes an alternative explanation, which uses a political-economy approach to conclude disconnect between the zero-sum understandings of political security perspectives within a liberal-capitalistic world order that thrives of positive-sum narratives. This paper shall exclusively use the case of a possible universal carbon taxation and the typologies thereof to conclude how a political-economy approach should be appropriate for a politicalsecurity end with regards to climate change.
\end{abstract}

Keywords: zero-sum game, capitalism, carbon tax, liberal institutionalism

\section{Introduction}

By the time of writing this piece, the world held in its hands these grim facts. Global fossil fuel emissions as measured in $\mathrm{GtCo}_{2}$ (Gigatonnes of $\mathrm{CO}_{2}$ ) have approximately increased by 20-percent in the past recorded decade with The People's Republic of China (henceforth referred to as the PRC) having had the most dramatic increase of approximately twice its 2005 fossil fuel emissions by 2016 (see table 1 for details). Another additional grim fact is 
the apparent rising temperatures of which along the 136-year data gathered, 17 out of 18 world's warmest year records have been occurring since 2001 (NASA, 2017). Conveniently then, Greenland and the Antartic Ice sheets, which accounts for more than 99-percent of the world's freshwater (NSIDC, 2018), are continuously losing mass at $127 \mathrm{Gt} / \mathrm{yr}$ and $286 \mathrm{Gt} / \mathrm{yr}$ rate (Gigatonnes/year) respectively (NASA, 2017). This then easily translates to the rise of sea levels which, conveniently again, have risen by more than a 100-percent between 2005 and 2017 (NASA, 2017). Moreover, the previous grim facts have then been calculably defined to have caused 4.9 million yearly deaths in 2010 according to the latest Climate Vulnerability Monitor report (DARA \& CVF, 2012). The report also predicts, that if current patterns of carbon use and climate changes continue, the deaths could go as far as 6 million yearly by 2030 . Deaths of which are caused by the direct consequences of carbon emissions and indirect ones through the damaging climate change effects (such as disasters, drought, and diseases) (DARA \& CVF, 2012).

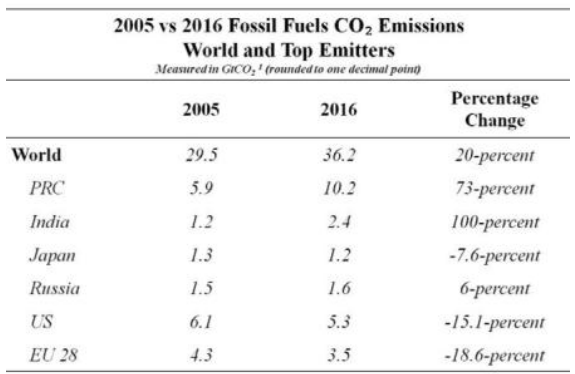

Table 1: Author's compilation from the Global Carbon Atlas interactive time series (Global Carbon Project, 2017)

Conclusively, should the science remain infallible, the grim facts that have been presented above are all interconnected as man-made climate change. Yet, this then begs the question as to why the world of nation-states have made insignificant progress in addressing the issue of climate change (as evident by the continuous increase of emissions globally) despite the overwhelmingly evident scientific consensus on the devastations man-made climate change can and have brought (NASA, 2017) (Klein, 2014, p. 12)(Klein, 2014:12). In fact, looking all the way back to the first transnational environmental cause that have produced a successful multilateral pledge, i.e. the Montreal Protocol which have to this date been deemed a success in restoring ozone concentrations (Barett, 2009:67), the current failings from 
the Kyoto Protocol onwards shall put us on a trajectory as predicted by the Climate Vulnerability Monitor. Furthermore, being conducted within the tenets of the international relations (IR) discipline, this paper shall question also the supposed rationality of the states' actions and responses to the destructive, debilitating and critical-to-survival threat of climate change. This paper shall also establish a priori the following premises: a) although the main questioning argument of this paper begins from a politicalsecurity perspective of which the approaches later discussed are to be traditional security oriented, this paper shall transcend the subdisciplines of IR by bringing the concept of interests as the lead bridging variable to the politicaleconomy approach, hence b) the research of this paper shall for the most part use the term (neo)liberal as a description of the current state of world market-based economic affairs (Clapp \& Dauvergne, 2005:239), not the dominant IR neoliberalism and or liberal institutionalism of Keohane, Nye and others (Lamy, 2011:114), unless otherwise stated. In other words, this paper contends that climate change is not the same kind of force within the political-security structures that shape state action/inaction to insecurities (caused by critical -tosurvival threats). It is actually the role of political-economic activities that fuel the continuous increase in threat of climate change impacts (therefore fueling insecurities to some, as will be explained later), not power imbalances or disruptions in state affairs.

\section{Rationalists Approach within IR}

Realism and its offshoots. Built upon the ashes of the Great European Wars (i.e. WWI and WWII), the realist IR approaches are credited to the ideas of Carr, Morgenthau and Niebuhr (Dunne \& Schmidt, 2011:84). The approaches of the early realists are based upon the assumptions of people's motives at the individual level which then translates into state action, and as Morgenthau has put it in his wellknown Six Principles of Political Realism, the motives of individuals are based upon human nature borne objective laws which then translates into rational human action/ inaction (Morgenthau, 1985). The arguments of the classical realists were then brought upon a higher order of analysis by the new realists (neorealists), who posits that it was not the individual human nature that 
causes state action/inaction, but the international structure of constant power and security struggles that shape state behavior (Dunne \& Schmidt, 2011:96). Writing in terms of a chronological order, what followed was the advent of the new classical realists (neoclassical realists) started by Gideon Rose (1998). The neoclassical realist approach brings back the individual unit factor as a variable of state conduct but at the same time acknowledging the power struggle structures put forth by neorealists. In other words, their approach 'places domestic politics as an intervening variable between the distribution of power and foreign policy behaviour' (Dunne \& Schmidt, 2011:90). Yet, with the understanding of a natural state of affairs, be it the individual, the structures surrounding the state or both at the same time, all approaches within the realist tradition continues upon the path of explaining state action/inaction through the theory of rational choice. The idea of rational choice, which draws upon behavioural economic studies, presupposes a political actor as utility maximizers, wherein self-interests dictates said actors to accrue as much gains with minimal losses (Brown \& Ainley, 2005:31).
In effect, as stated by Dunne (2011), there is a significant degree of continuity along the evolution of realist thoughts wherein three core elements, known as the 3S (Statism, Self-help \& Survival) persists amongst the various realist offshoots. Statism is understood as a given due to the anarchic conditions of the world, hence the highest order of exercised authority is only done by states. Self-help is the only principle action states adhere to in an anarchical world, due to the fact that there is no higher order to assist their conducts. This is contrasted to how states are responsible for the individual populations within them. Survival is what shapes rational action according to realists, the most basic instinct of human nature is that of staying alive, hence any conducts thereof is to satisfy said instinct (Dunne \& Schmidt, 2011:94).

\section{Liberalism and its offshoots.} An understanding of liberalism can go all the way back to the mid-19 th $_{\text {h }}$ century ideas of Richard Cobden, who contends that the causes of conflict are extensive interventions to the idea of individual liberties which causes disturbances to the natural order of the freedom of human conduct. Moreover, the ideas of liberalism founded by 
Woodrow Wilson and J.A. Hobson then bring in the democratic nature and power balances as variables that, if disturbed, shall cause conflict (Dunne, 2011:103). It is also convenient that the liberal approach is in agreement with the realist camp that the world state of affairs is anarchic with the highest order of exercised authority only being done by states (Dunne, 2011:103). Unlike, the Realist's perspective with its chronologically ordered birth of offshoots, the new liberalism (neoliberalism) grew out of the pluralistic critiques of the realist theories (Brown \& Ainley, 2005:45). The neoliberals or otherwise dubbed as liberal institutionalists suggest that the way towards peace is for states to surrender a portion of their sovereignty as evidenced by the development of the European Union (Lamy, 2011:121).

As complex processes of development continued and the technological processes brought along with it, what became of interdependences, wherein state conduct are increasingly bind together, became the backdrop of further neoliberal theories. The neoliberals, do accept that anarchy exists as well as self-serving interests of the states, but due to the complex interdependences structured, state conduct can be done, if not more beneficial, in cooperation (Brown \& Ainley, 2005:47). One method of cooperative conduct is through international regimes, which is defined as 'principles, norms, rules, and decision-making procedures around which actor expectations converge in a given issue-area' (Krasner, 1982:185). International institutions therefore, serve as a platform for said international regimes. However, in effect, even though the leading variables perceived more important by liberals differ to those of realists, the two are in accordance when both their explanation of state action/ inaction is based upon rational choice conduct (Brown \& Ainley, 2005:47).

\section{Rationalist Attempt at Climate Change}

Considering the proclaimed dominance of the rationalist approaches as supposed explanatory devices to state action/inaction within international relations conduct (Brown \& Ainley, 2005:32), it is then stressed again the apparent disconnect between the overwhelming evidence of criticalto-survival climate change and states' continuous insignificant action towards addressing it. Both 
the realists and liberalists as rational theories agree that actions of state mainly serve survival instincts. That being said, for a realist, an increase of perceived threat from another party towards a state shall create insecurity which then provides an impetus for state actions of minimizing said threat (in the realist camp, through activities such as bandwagoning or balancing) (Dunne \& Schmidt, 2011:84). Even the proclaimed realist argument of Morgenthau assumes states behave to the point of, for better or for worse, immorality which is driven by that survivalist instinct (Tickner, 2009:15). As for the liberalist, a method of averting conflict, or the fear of conflict is done through cooperative conduct (Dunne, 2011:106). Therefore, a formed threat engenders a rational response. Rationality, of course, is the instinctual guide to ensuring survival. However, as evident by the continuous process of climate change, and in addition to that, the severely lacking prescriptions borne out of multilateral arrangements and state action (Klein, 2014:123), the question in mind is then, either the states are not rational at all or the theories brought forth trying to explain that states are rational are inappropriate for this issue.
Despite the already negated rational survival-instinct premise of realism vis-à-vis climate change, Heffron (2015) make further attempts at fitting the realist theoretical lens upon climate change action/inaction. In Heffron (2015), climate change is defined as a global threat that is indiscriminate of states and state borders. Yet, despite being indiscriminate and very real, the various strands of realism only continue to analize 'war, conflict, geopolitics, alliances and balancing behaviours, and the way states operate in the international system' and hence 'realism has very little or nothing to say about possible solutions to climate change' (Heffron, 2015:8). A significant argument put forth in Heffron (2015) is the idea of carbon bandwagoning as a signifier of states action/inaction to climate change. The argument follows the idea that as state A pursues rational conduct of reducing carbon emissions through lowering reliance on fossil fuels, another state B may 'bandwagon off the back of these efforts and burn more fossil fuels' hence rendering the efforts by state A irrelevant in addition to the relative losses to state A (Heffron, 2015:10). Heffron (2015) argues that the relative losses become important climate 
mitigation efforts by state A may not bring much immediate benefits that would counteract the losses ceded to state B-he explains this in terms of resource allocations of military capabilities wherein, state A may reduce resources allocated towards the military to increase climate mitigation efforts, and the resulting behaviour of state B would be taking advantage of state A's dwindling down military capability hence creating traditional spiral of insecurity (security dilemma, see Dunne \& Schmidt, 2011:95).

The argument of carbon bandwagoning posited by Heffron (2015), in effect, concludes that state inaction towards climate change is due to fears that climate change action be taken advantage by other states hence stimulating a spiral of insecurity which then averts all attention to the climate issue at the beginning. The problem with the carbon bandwagoning assumption of state inaction is that the realities presented do not follow the same logic. As presented in Table 1, there are actors who have seen reductions in fossil fuel emissions amid increases by other actors. At the same time, the increase of fossil fuel emissions by India and the PRC for instance is way more than the reductions introduced by other top emitters. Additionally, Kreft et. al (2017) and Verisk Maplecroft (2016) reports that the PRC and India is significantly more at risk to the effects of climate change than other top emitters. In other words, the facts presented at hand further disproves the rational arguments claim from the realist bandwagoning assumption as posited by Heffron (2015) because, the PRC and India stands to lose much more, and to that end is more threatened survivalwise by climate change (Verisk Maplecroft, 2016) (Kreft, et al., 2017). Moreover, India has actually made considerable losses in the year 2015 due to extreme weathers and disasters attributable to climate change (Kreft, et al., 2017) in the run-up to the Paris Climate Accords, which it committed to only slightly by the pledge of greenhouse gases reductions given (Mizo, 2016:376).

Another realist-originated argument have also been proposed by Purdon (2017), wherein he specifically addresses the action/ inaction towards climate change by states through the lens of the neoclassical realist perspective. In Purdon (2017), the neoclassical realist thought presented, explains that there are 'systemic concerns on climate change cooperation' due to 
'relative-gains concerns associated with international resource transfers implicit in climate change policy'. The resource transfers which this paper, in agreement with Purdon (2017) and Klein (2014), also contends as the most significant mode of climate change mitigation, pending significant scientific breakthrough, then becomes a signifier into understanding the political forces that shape state behaviour. In other words, there are conflicting forces domestically in addition to the international structured forces that compels state to act or not to act upon climate change (Purdon, 2017:267). Purdon (2017), goes further by testing his perspective upon the two forms of international climate finance: carbon markets and climate funds.

In short, the two, supposedly forms of resource transfers and trading mechanism are built upon the bedrock of the neoliberal economic order (Purdon, 2017:269). The international structures then shape state behaviour by tapping the relative gains concerns as balance and or security have been disturbed by the significant resource transfers, similar to the argument made in Heffron (2015). This is evident in Canada's decision to withdraw from the Kyoto Protocol which gave birth to the Clean Development Mechanism $(\mathrm{CDM})$, the initial multilateral carbon market, due to the notable systematic wealth transfers away from Canada the mechanism entails (Purdon, 2017:281). As for climate funds being, straightforwardly, a form of wealth transfers, the realities presented has been selfevident with financing pledges not always materialized into deposits and the number of countries actually engaging in climate funds is much lower than those active in the carbon markets (Purdon, 2017:282). In addition to that, as domestic politics also shape state behaviour, the neoclassical realist perspective contends that the popularity of carbon markets is due to the perceived ability of continued gains from taking advantage of the CDM and others (such as the EU Emissions Trading Scheme) by domestic actors, and that disengagement is a path taken once the carbon markets appeal no-longer to the self-interested actors within the state. The example of disengagement is evident by Canada again, in its critique towards the carbon market as essentially a potential waste taxpayers' money, which is a domestic actor concern, 
particularly political constituencies (Purdon, 2017:281).

Yet, despite the compelling case presented with carbon markets and climate funds by Purdon (2017) that can be analyzed through the neoclassical realist lens, the relative gains concern from disturbances within international structures have been presented before by Heffron (2015), and hence can still be dispelled using the same arguments proposed previously with continuous reductions of emissions by specific emitters and the vulnerability positions that other specific emitters are in. Should attention be given then, to the domestic politics, which constitutes of various overlapping and conflicting self-interests, which shape state behaviour, the simple rationalist survival-instinct premise already negates this argument as overwhelming evidence of threat continuously presents itself amid significant state inaction at the same time. This paper shall also concur that the neoclassical realist approach in itself is inherently problematic as, Quinn (2013) concludes. As the approach, in its attempt to develop

a law-like explanation of state behaviour actually goes beyond the limits of the rational aspect of the realist paradigm as well as sidelining, though not completely, the systemic imperatives of structural realism (Quinn, 2013:160).

What then, can be made of the liberalist approach to explaining significant state inaction towards climate change is just as straight forward. As the rational argument have been completely dispelled, we can also consider how states have yet made significant action, even cooperatively, in that manner to mitigate climate change and hence maintain survivalist security (Clapp \& Dauvergne, 2005:249). Hence, even as liberal institutionalists make an attempt to justify states tendency to push for cooperation based on so called 'absolute-gains' and that they shall stand to lose to the impacts of climate change if they do not do so (Clapp \& Dauvergne, 2005:252), the facts of current cooperative arrangements are considerably lacking in both progress and effect (Klein, 2014:123). For the most part, explanations given by institutionalists, according to Clapp and Dauvergne (2005) only refer to the symptoms of state action/ inaction and that improving institutional mechanisms, coordinating platforms and regimes will give birth to climate change mitigating solutions. The criticism then, is how strong the institutions, 
regimes or coordinating platform must become is a never- ending goalpost shifting by the institutionalists, as the current state of institutions should be enough for coordinating measures to act against climate change (Clapp \& Dauvergne, 2005:241).

To further argue against the institutionalist approach, one can look at declaration at the Copenhagen Climate Change 2009 conference wherein, the scientific consensus of the dangers of a 2-degree Celsius average temperature rise, which was determined all the way back prior to the Kyoto Protocol, was formally recognized. Yet, despite the scientific warning of the temperature rise, it was only by the Paris Agreement of 2015 that the 2- degree Celsius global temperature target gained legal recognition in the form of an adhered to international treaty (Gao, et. al., 2017:274). Of course, the 2 -degree Celsius target was never a considerably sufficient target to revert or at least fight back climate change as evident by the death-sentence still given to significant coastline populations across the world with sealevel rises (Gao, et. al., 2017:273) (Jex, 2015). Which then is the reason, that a more scientifically safe level of 1.5-degree Celsius average
temperature rise is thrown into the mix within the Paris Agreement of 2015 albeit the 2-degree Celsius target, which is more politically convenient, gaining the spotlight (Gao, et. al., 2017:274). So in effect, the international realm is not necessarily lacking in comprehensive institutional structures, it is just that the states which cede power to them is signi-ficantly not acting enough on purpose despite the scientific consensus (Klein, 2014:20).

\section{Climate Change and the Dualistic Ideologues}

To wrap up the rationalist camp attempts at climate change, the theories they've proposed only go as far as explain how and what of state action/inaction towards climate change, rather than why. So, even if one presupposes the preordained games of survival that the rationalists claim states are primed to go about naturally (Brown \& Ainley, 2005:91), the presented facts and realities show that there remains significant inaction that would otherwise prove rationality. The explanation this paper proposes then, is through the constructivist paradigm, where one point of critique is towards said assumptions of a preordained rationality within a conditioned system that prompt 
survivalist instincts. In short, states are not inherently primed towards survival, as rationalists may claim. On the contrary, the ideas that define them are what determine their subjective perception of rationality (Brown \& Ainley, 2005:112). The constructivist approach, being postpositivist in method, goes beyond the stringent empirical methods of positivists, which, within the realm of IR is embraced by the rationalists who establish law-like generalizations based on quantifiable material capabilities of the states (Parsons, 2015:510)

Following upon Cho (2012) who states that 'insecurities themselves are not pre- given and natural things which exist separately, but are produced in a mutually constitutive process', the idea of climate change acting as a threat to survival depends much upon the ideologues who perceive them. What is perceived as insecurity in one state, may not be perceived as so in another state. The stressing point being the constructed perception which is shaped by context and ideas (Cho, 2012:309). In other words, the perception of security completely differs to objective rational action towards security. To analogize, it is a scientific human condition for a flight or fight and adrenaline-induced response to a direct physical threat. Yet, whatever built perceptions or unawareness, could cover said response from ever being catalyzed. This is because to an individual never knowing the constructs of a gun, being held at gunpoint would most probably translate to an irresponsive action unlike the individual who knows best the killing capability of a gun who would probably have their survivalist instincts triggered. According to Klein (2014), the driving issue that created the rift of differing perceptions is the advent of neoliberal capitalism, specifically the continuously deregulated one within an international anarchic system. Connecting the aforementioned arguments to the political-economy sphere then brings up a dualistic rationality construct wherein particular states adherent to rational security concerns may engage in climate change mitigation (that is, through fossil fuel emissions reductions as done by EU 28, see Tabel 1). Whereas other states such as the PRC and India remain adherents to the purview of the political-economic sphere enhancement (Pan, et. al., 2009:150) (Joshi \& Patel, 2009:171).

Moreover, it must be pointed out again that, what is meant 
by rational security concerns of countries such as the EU 28 or the US is not the same as assumptions of the rational realists who presumed inaction towards climate change by state $\mathrm{A}$ is due to fears of carbon bandwagoning by state $\mathrm{B}$, because as figured by Pan et. al (2009), the emissions of the PRC is a substitute for the decreases of emissions in the developed world. In short, the reductions of emissions by the EU 28 and the US is done under a constructed influence of survivalist concerns which then primes climate mitigation effort narratives (Cass, 2007:237) not the rationalist claims of inherent survivalist -instincts. This is because, as argued previously, current state actions still does not compute towards effectively trying to actually survive (Helm, 2009:16). Going back to the previous analogy then, there is an obvious difference between a triggered survivalist instinct by fighting then trying to pull then gun away, and turning ones back and running away. The latter, of course, results in being gunned down anyway, though the slightest seconds of survival was maintained, this is not dissimilar to minimal efforts by the EU 28 and the US who have built the perception amongst themselves to maintain slight seconds of survival instead of putting a permanent end to the threat. Actions of the PRC and India on the other hand is that of bargaining with the one holding the gun whose naturally preconditioned to always shoot, in other words a futile attempt. The naturally occurring fact is that once emissions are up, the carbons stay for a lengthy period (Klein, 2014:204), hence subscribing to notions that development comes first through theories like environmental Kuznets Curve presented by neoliberals and liberal institutionalists alike (Clapp \& Dauvergne, 2005:91) amounts to the analogy presented above and shows the apparent disconnect.

In retrospect, the context that brought us here is a set of historical antecedents which shifted our idea of a global commons into a commodified private property as explained by Max Koch (2012), and a societal-value shift that disrupted the notions of the collective good as explained by Klein (2014). So then, to follow upon the argument Riviere (2015) who states the contestable environmentalist norms that are slowly being constructed, this paper contends that what is being contested is the reigning hegemonic construct of blind capitalism. The environmentalist norms which evidently is gaining ground (Cass, 
2007:238), is currently still subject to perversions of materialistic reasons hence the continued lack of significant action (Riviere, 2014). In addition to that, considering how constructed ideas within IR is a collective manifestation of the citizens within, the varying degree of climate change mitigation then makes sense as the worship of blind capitalism differs from state to state (Riviere, 2014:92). Moreover, the continuous positive-sum promises demonstrated by capitalistic expansion fuelling rise of $\mathrm{CO}_{2}$ emissions, is not followed by the scientific evidence of equal availability of carbon-sinks, hence zero-sum (as the loss is towards a collective global common ownership) in reality because there can only be so much $\mathrm{CO}_{2}$ emissions until a breaking point is reached (Koch, 2012:31). In other words, the current societal constructs fuels the process of accumulation by dispossession (Koch, 2012:109).

\section{Constructing Prescriptions: Carbon Tax dissemination}

As significant objective action is then required to tackle climate change which is perceived as a threat in varying degrees due to contextual ideologue constructs, this paper proposes the idea of constructing a specific politicaleconomic idea: i.e. carbon taxation. The carbon taxation proposed here is not exactly an economic step-bystep policy prescription, but rather a constructed social idea of exchange and behaviour shaping that goes beyond the bounds of the synthesizing capitalist and environmentalist norms. The reason being that, current prescriptions are still bound to the compromises of privatization and commodification of the global commons, hence ideas remain restricted to climate funds and carbon markets of which the results to this day provide no significant cheer as to effect in reverting climate change (Hepburn, 2009:377). In fact, the current market-based constructed approach, rather than social-approaches to climate change is so perverted that once the carbon markets were introduced, accumulative behaviour took place more significantly as speculations and price manipulations became the norm of the carbon market instead of fulfilling an environmentally clean end (Koch, 2012:104).

In terms of effect, by introducing a social-policy like carbon tax, there will be a reshaping of consumption patterns on the household side and a limitation on negative externalities 
of productions, both of which would then translate to a reduction of overall emissions (Mankiw, 2009:373). Yet, at the same time, in no way shape or form does this paper try to propose the introduction of carbon taxes as a compromising tool that would be politically salient as to promise and or maintain economic growth. On the contrary, as established throughout the entirety of this paper, what needs to be introduced are mechanisms that would completely revert the damage that has been done by irrational ideologues towards the global commons, i.e. carbon sinks (Klein, 2014:18). Needless to say, the proposed carbon taxes is a radical-free alternative approach to extreme environmentalists who would otherwise promote revolutions or taking down current structures instantaneously so as to save the environment (Clapp \& Dauvergne, 2005:252). The premise of this social carbon tax approach for a security end, i.e. survival is that taxation is a method that stays within the tenets of current constructed politicaleconomic ideologies but is also contesting it at the same time. In effect, through carbon taxes, the idea of profit accumulation and endless growth supported by positive-sum narratives must be slowly hold back enough to level with the scientific consensus of carbon sink capacities (Klein, 2014:18). That being said, this paper presents three main types of carbon taxes that could be employed domestically, best suited to the context of country resource utilization as well as patterns of emission.

Sectoral Carbon Tax. This type of carbon tax, shall place the burden of emissions negativities particularly on those sectors that most produce emissions, provided that there would be no significant factored leakages (Baylis, et al., 2013). Leakages, according to Baylis et. al (2013) is when reductions of emissions in one sector shall trigger a shift of the emissions elsewhere. The example to this is the taxation done to the electricity, cement and some manufacturing sectors within the EU, the resulting end of which do not increase emissions elsewhere (Baylis, et. al., 2013:337).

\section{Border Carbon Adjustments} (BCA). Otherwise termed Border Tax Adjustments, is a taxation method that assures 'emissions reductions achieved within a country through a tax (production tax) are not totally offset by the increase 
in emissions that occurs in partner countries by virtue of expanded trade' (Matoo, et. al., 2013:588). In short, BCAs ensure that the conditions of emission freeriding do not occur (as explained with the PRC offsetting emissions reductions of the developed world in part three).

Fossil Fuel Tax (Energy Tax).

This tax, as the name suggests, aims at one of the core of emissions itself. Countries would tax the fossil fuel use and production within their borders (McLure Jr., 2014:553). The general application of this goes by targeting content rather than simply usage and or production. Which means that the more harmful substance would have its usage reduced (OECD, 2016:15).

\section{Conclusions}

Supposing that there are states $\mathrm{A}$ and $\mathrm{B}$ living in an anarchic international system. State A decides to increase its material capability (be it economic or military) so it becomes twice that of state B. Not long after, state $\mathrm{B}$ increases its material capability to level. What the rational realists see is insecurity of state B and the need to ensure its survival prompting it to buildup. The liberalist on the other hand, firstly blames the lack of coordination between the states because state B's increase of material capability to level is due to unavailable assurances by state A through bridging institutions that the increase of material capability was not for harms use. The constructivist paradigm, subscribed by this paper, would question what other states $\mathrm{C}, \mathrm{D}$ and $\mathrm{E}$ are doing, which presumable are not generalized as state B's action, provided that the context of ideas shaping action within these states differ. Yet what if state A is changed into a global common and its increase in material capabilities is climate change? Well, the logic of the rationalists then dictates that there are no two-ways to go about it, and changing behaviour (through patterns of emissions) is the only way to go about reducing climate change's potential harm. But that is not what has happened.

The arguments brought forth in this paper, however, is not an attempt to completely dismiss the rationalist arguments. In fact, had we live in a rationalist world, there would have been many significant progress towards climate change mitigation right now, or 
perhaps none of its harms have come forth. Instead, the current world constructs is populated by irrational ideologues, and a shift of ideas is needed more than ever if we are to survive. Perhaps best if policies, prescriptions and the likes subscribe to the ideas of a global commons under tragedy (Hardin, 1968:1247). Yet, subscribing to the constructivist paradigm means accepting a pluralistic realm of the IR discipline because even ideas are shaped by ideas, hence any further discussions on this paper's outcome is most welcome.

\section{Bibliography}

Alvesson, M. \& Skoldberg, K., 2009. Reflexive Methodology: New Vistas for Qualitative Research. London: SAGE Publications.

Barnett, M., 2011. Social Constructivism. In: J. Baylis, S. Smith \& P. Owens, eds. The Globalization of World Politics: An Introduction to International Relations. New York: Oxford University Press, pp. 150 - 164.

Barrett, S., 2009. Climate Treaties and the Imperative of Enforcement. In: D. Helm \& C. Hepburn, eds. The Economics and Politics of Climate Change. New York: Oxford University Press, pp. 58 - 80.
Baylis, K., Fullerton, D. \& Karney, D. H., 2013. Leakage, Welfare, and Cost-Effectiveness of Carbon Policy. The American Economic Review, May, 103(3), pp. 332 - 337.

Brekke, K. A. \& Johansson-Stenman, O., 2009. The Behavioural Economics of Climate Change. In: The Economics and Politics of Climate Change. New York: Oxford University Press, pp. 107 $-124$.

Brown, C. \& Ainley, K., 2005. Understanding International Relations. 3rd ed. New York: Palgrave Macmillan.

Carl, J. \& Fedor, D., 2016. Tracking Global Carbon Revenues: A Survey of Carbon Taxes versus Cap-and-Trade in the Real World. Energy Policy, Volume 96, pp. 50 - 77.

Cass, L. R., 2007. Measuring the Domestic Salience of International Environmental Norms: Climate Change Norms in American, German, and British Climate Policy Debates. In: The Social Construction of Climate Change: Power, Knowledge, Norms, Discourses. Hampshire: Ashgate Publishing Limited, pp. 23 - 50. 
Cass, L. R. \& Pettenger, M. E., 2007. Conclusion: The Constructions of Climate Change. In: The Social Construction of Climate Change: Power, Knowledge, Norms, Discourses. Hampshire: Ashgate Publishing Limited, pp. 235 246.

Cho, Y. C., 2012. State Identity Formation in Constructivist Security Studies: A Suggestive Essay. Japanese Journal of Political Science, September, 13(3), pp. 299 - 316.

Clapp, J. \& Dauvergne, P., 2005.

Paths to a Green World: The Political Economy of the Global Environment. 1st ed. Massachusetts: MIT Press.

DARA \& CVF, 2012. Climate Vulnerability Monitor,

Madrid: DARA.

Depledge, J. \& Yamin, F., 2009. The Global Climate-change Regime: A Defence. In: The Economics and Politics of Climate Change. New York: Oxford University Press, pp. 433 - 453.

Dunne, T., 2011. Liberalism. In: J. Baylis, S. Smith \& P. Owens, eds. The Globalization of World Politics: An Introduction to International Relations. New York: Oxford University Press, pp. $102-111$.
Dunne, T. \& Schmidt, B. C., 2011. Realism. In: J. Baylis, S. Smith \& P. Owens, eds. The Globalization of World Politics: An Introduction to International Relations. New York: Oxford University Press, pp. 86 - 96.

Gao, Y., Gao, X. \& Zhang, X., 2017.

The $2{ }^{\circ} \mathrm{C}$ Global Temperature Target and the Evolution of the Long-Term Goal of Addressing Climate Change: From the United Nations Framework Convention on Climate Change to the Paris Agreement. Engineering, 3(2), pp. 272 - 278.

Global Carbon Project, 2017. CO2 Emissions. [Online] Available at: http://www. globalcarbonatlas.org/en/CO2emissions

Hardin, G., 1968. The Tragedy of the Commons. Science, 13 December, 162(3859), pp. 1243 - 1248.

Heffron, D., 2015. What do realists think about climate change? Centre for Geopolitics \& Security in Realism Studies, pp. 2 - 21.

Helm, D., 2009. Climate-change Policy: Why has so Little been Achieved?. In: The Economics and Politics of Climate Change. New York: Oxford University Press, pp. 1 - 22. 
Hepburn, C., 2009. Carbon Taxes, Emissions Trading, and Hybrid Schemes. In: The Economics and Politics of Climate Change. New York: Oxford University Press, pp. 365 - 384.

Jex, C., 2015. COP21: What does two degrees Celsius global warming look like?. [Online] Available at: http:// sciencenordic.com/cop21-w hat - do es - t wo - deg re es celsius-global-warming-look

Joshi, V. \& Patel, U. R., 2009. India and Climate-change Mitigation. In: The Economics and Politics of Climate Change. New York: Oxford University Press, pp. 167 - 196.

Kegley Jr., C. W. \& Blanton, S. L., 2011. World Politics: Trend and Transformation. Boston: Wadsworth Publishing.

Klein, N., 2014. This Changes Everything: Capitalism vs. The Climate. Toronto: Alfred A. Knopf Canada.

Koch, M., 2012. Capitalism and Climate Change: Theoretical $D$ i s cu ssion, Hi stor ical Development and Policy Responses. New York: Palgrave Macmillan.

Krasner, S. D., 1982. Structural C aus es and Regime
Consequences: Regimes as Intervening Variables. International Organization, 36(2), pp. 185 - 205.

Kreft, S., Eckstein, D. \& Melchior, I., 2017. Global Climate Risk Index 2017, Berlin: Germanwatch.

Lamy, S. L., 2011. Contemporary mainstream approaches: neorealism and neo-liberalism. In: J. Baylis, S. Smith \& P. Owens, eds. The Globalization of World Politics: An Introduction to International Relations. New York: Oxford University Press, pp. 114 - 129.

LO, A., 2013. The Political Economy of Carbon Tax: International Practice and the Australian Model. Chinese Journal of Urban and Environmental Studies, 1(1), pp. 1 - 15.

Mankiw, N. G., 2009. One Answer to Global Warming: A New Tax. In: International Politics: Enduring Concepts and Contemporary Issues . New York: Pearson, pp. 372 - 374.

Mattoo, A., Subramanian, A., Mensbrugghe, D. v. d. \& He, J., 2013. Trade effects of alternative carbon border-tax schemes. Review of World Economics, September, 149(3), pp. 587 - 609. 
McLure Jr., C. E., 2014. Selected International Aspects of Carbon Taxation. The American Economic Review, May, 104(5), pp. 552 - 556.

Mizo, R., 2016. India, China and Climate Cooperation. India Quarterly, 72(4), pp. 375 - 394.

Morgenthau, H. J., 1985. Politics Among Nation. s.l.:Alfred A. Knopf.

NASA, 2017. NASA Global Climate Change - Vital Signs of the Planet. [Online] Available at: https:// c 1 i m a t e. n a s a.gov/vi t a 1 signs/global-temperature/

[Accessed 20 March 2018].

NSIDC, 2018. State of the

Cryosphere. [Online] Available at: https:// n s i d c . org/cryos phere/sotc $/ \mathrm{i} \mathrm{ce}_{-} \mathrm{sh}$ e e t s.h t m l [Accessed 20 March 2018].

OECD, 2016. Effective Carbon Rates: Pricing CO2 through Taxes and Emissions Trading Systems, Paris: OECD Publishing.

Otaki, M., 2013. Emission Trading or Proportional Carbon Tax: A Quest for More Efficacious Emission Control, Tokyo: DBJ Research Center on Global Warming.
Pan, J., Phillips, J. \& Chen, Y., 2009. China's Balance of Emissions Embodied in Trade: Approaches to Measurement and Allocating International Responsibility. In: The Economics and Politics of Climate Change. New York: Oxford University Press, pp. 142 $-166$.

Parsons, C., 2015. Before eclecticism: competing alternatives in constructivist research. International Theory, November, 7(3), pp. 501 - 538.

Pettenger, M. E., 2007. Introduction: Power, Knowledge, and the Social Construction of Climate Change. In: The Social Construction of Climate Change: Power, Knowledge, Norms, Discourses. Hampshire: Ashgate Publishing Limited, pp. 1 - 22.

Purdon, M., 2017. Neoclassical realism and international climate change politics: moral imperative and political constraint in international climate finance. International Relations and Development, 20(2), pp. 263 - 300.

Quinn, A., 2013. Kenneth Waltz, Adam Smith and the Limits of Science: Hard choices for neoclassical realism. International Politics, 50(2), pp. 159 - 182. 
Riviere, L. L., 2014. Towards a Constructivist International Political Economy of Climate Change. Issues in Political Economy, Volume 23, pp. 90 101.

Tickner, J. A., 2009. A Critique of Morgenthau's Principles of Political Realism. In: International Politics: Enduring Concepts and Contemporary Issues. New York: Pearson , pp. 15 - 28. Verisk Maplecroft, 2016. Climate Change Vulnerability Index 2017, s.1.: Verisk Maplecroft. 